\title{
Bioeconomy Concepts
}

\author{
Regina Birner
}

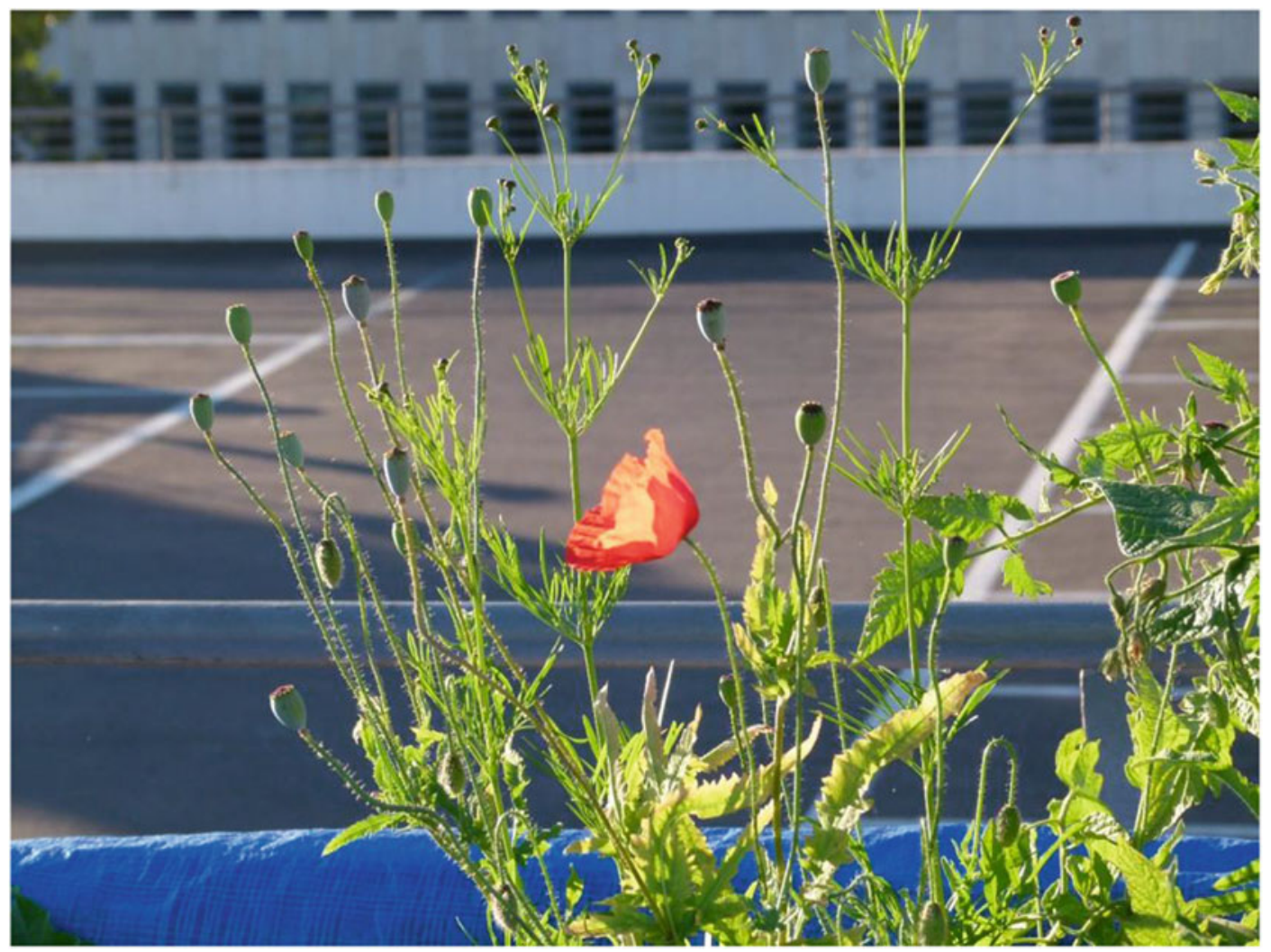

Urban gardening on a parking deck in Stuttgart. (C) Ulrich Schmidt

R. Birner $(\bowtie)$

Hans-Ruthenberg-Institute, Social and Institutional Change in Agricultural Development, University of Hohenheim, Stuttgart, Germany

e-mail: Regina.Birner@uni-hohenheim.de

I. Lewandowski (ed.), Bioeconomy, https://doi.org/10.1007/978-3-319-68152-8_3 


\begin{abstract}
This chapter consists of three sections. The first section deals with the origin and evolution of the concept of the bioeconomy. It starts by tracing the first uses of the terms bioeconomics and bioeconomy and goes on to review the development of the concept of the "knowledge-based bioeconomy" in the European Union before discussing the rise of the bioeconomy as a global concept. A shift from a "resource substitution perspective" of the bioeconomy to a "biotechnology innovation perspective" is identified. Critical views of the bioeconomy are discussed, distinguishing a "fundamental critique" and a "greenwashing critique" of the bioeconomy. The first section of this chapter also reviews the relations between the concept of the bioeconomy and the concepts of "sustainable development", "green economy", "circular economy" and "societal transformation". The second section of the chapter discusses the bioeconomy strategies that an increasing number of countries around the world have adopted in recent years. This section uses a competitiveness framework to classify different elements of the bioeconomy strategies. The third section of the chapter is concerned with bioeconomy governance, focusing on the different actors in the bioeconomy, the ways in which they interact and the governance challenges that they are confronted with.
\end{abstract}

\title{
Keywords
}

Bioeconomy concepts - Knowledge-based bioeconomy - Bioeconomy strategies $\bullet$ Bioeconomy governance

\section{Learning Objectives}

This chapter should enable the reader to:

- Define the term bioeconomy.

- Understand the origin and evolution of the concept of the bioeconomy.

- Be familiar with diverse perspectives on the bioeconomy.

- Understand the relation between the concept of the bioeconomy and the concepts of sustainable development, green economy, circular economy and the great societal transformation.

- Classify the components of bioeconomy strategies and policies.

- Identify the key stakeholders of the bioeconomy and understand their relations.

- Understand key challenges of bioeconomy governance.

\subsection{The Concept of the Bioeconomy: Origin and Evolution}

\subsubsection{The First Use of the Terms "Bioeconomics" and "Bioeconomy"}

The use of the term "bioeconomics" can, according to Bonaiuti (2014, p. 54), be traced back to Zeman, who used the term in the late 1960s to designate an economic order that appropriately acknowledges the biological bases of almost all economic activities. As Bonaiuti (2014, p. 54) further explained, GeorgescuRoegen "liked the term and from the early 1970s made it the banner summing up the most 
important conclusions he had come to in a lifetime of research". An essential element in Georgescu-Roegen's use of the term bioeconomics was his concern that unlimited growth would not be compatible with the basic laws of nature (Bonaiuti 2014, p. 54).

This use of the term "bioeconomics" is rather different from the early use of the term "bioeconomy", which referred to the use of biological knowledge for commercial and industrial purposes. As pointed out in Chap. 4, one can consider this rather contrasting use of the two terms as an "irony of fate". According to von Braun (2014, p. 7), the term was first defined by the two geneticists Juan Enriquez Cabot and Rodrigo Martinez. A paper published by Enriquez in the Science magazine in 1998 (Enriquez 1998) is also quoted as a source for this use of the term (Gottwald 2016, p. 11). In this paper, which is entitled "Genomics and the World's Economy", Enriquez discusses that the application of the discoveries of genomics will lead to a restructuring in the role of companies and industries "in a way that will change the world's economy". He outlined "the creation of a new economic sector, the life sciences" in this paper (Enriquez 1998, p. 925). Though this paper does not use the term "bioeconomy", the source represents one of the roots of the concept of bioeconomy: advancements in the biological sciences and in biotechnology, which have the potential to transform many industrial production processes. The view that the "biological revolution" would eventually transform the industry was, however, not new at that time. The "industrial impact of the biological revolution" was already formulated in the early 1980s (Glick 1982).

\subsubsection{The Development of the Concept of the "Knowledge-Based Bioeconomy" in the European Union}

Even though the term bioeconomy was first introduced by scientists concerned with the industrial consequences of advancements in biology, the major reason why bioeconomy became an important policy concept in Europe was a deliberate decision by staff members of the European Commission to promote this concept. One of the key actors in this effort was Christian Patermann, the former Program Director of "Biotechnology, Agriculture and Nutrition" in the Directorate General for Research, Science and Education of the European Commission. According to his own account, the term "bioeconomy" was used by a conference of Ministers of Environment. ${ }^{1}$ The term had not been further specified by the members of that conference, but Patermann and his colleagues realized that the concept had a unique potential as a policy concept that would allow the EU to respond to new opportunities. One opportunity was making economic use of the emerging new potential of using biotechnologies, as indicated above. Another opportunity inherent in the concept of the bioeconomy is the replacement of fossil-based resources by bio-based resources, both for energy and for material use. In the early 2000s, decision-makers in the EU felt a strong incentive to find new concepts, because the need for increasing agricultural productivity to meet future needs for food and biomass was not very well recognized at the time. Funding for agricultural research, which is key to increasing agricultural productivity, had declined throughout the 1990s in spite of the emerging need to produce biomass for other uses than food (Geoghegan-Quinn 2013).

In developing the concept of the bioeconomy in the EU, the label "knowledge-based" was added so that it became the "knowledge-based bioeconomy". The label "knowledge-based" was in line with the EU innovation policy that prevailed at the time. At a meeting in Lisbon in 2000, the European Council had made a commitment to establish "the most competitive and dynamic, knowledge-based economy in the world" (EU 2000). As pointed out in Sect. 3.1.4 in

\footnotetext{
${ }^{1}$ Personal communication with Dr. Christian Patermann, 29.04.2013, Berlin.
} 
more detail, the concept of the knowledge-based economy reflects the vision of achieving economic growth through high-technology industries, which requires investments in innovation and highly skilled labour.

The efforts of the EU to promote the concept the knowledge-based bioeconomy proved remarkably successful. In 2005, the European Commission held a conference entitled "New Perspectives on the Knowledge-Based Bio-Economy" (EC 2005). At this conference, Janez Potočnik, the European Commissioner for Science and Research, gave a speech entitled "Transforming life sciences knowledge into new, sustainable, eco-efficient and competitive products" (Potočnik 2005). In the so-called Cologne Paper of 2007, this title has been quoted as a definition of the knowledge-based bioeconomy. The Cologne Paper was based on a workshop held under the German Presidency of the Council of the European Union in 2007 in the city Cologne. The workshop was attended by experts from research organizations and companies covering different fields, including crop production, biotechnology, bioenergy and biomedicine (EU 2007). The Cologne Paper emphasized the two dimensions of the bioeconomy mentioned above:

- On the one hand, the paper identified the role of biotechnology as "an important pillar of Europe's economy by 2030, indispensable to sustainable economic growth, employment, energy supply and to maintaining the standard of living" (EU 2007, p. 4). One can label this dimension of the bioeconomy "the biotechnology innovation perspective".

- On the other hand, the Cologne Paper stressed the use of crops as "renewable industrial feedstock to produce biofuels, biopolymers and chemicals" (EU 2007, p. 4). The paper also envisaged that "by 2020, in addition to the then mature gasification technologies, the conversion of lignocellulosic biomass by enzymatic hydrolysis will be standard technology opening up access to large feedstock supplies for bioprocesses and the production of transport fuels". One can label this dimension of the bioeconomy "the resource substitution perspective".

The changing emphasis of these two perspectives over time is further discussed in Sect. 3.1.4. The development of the concept of the bioeconomy was accompanied by increased funding, especially in the EU's Framework Programs for Research and Technological Development, most notably in the current 8th Framework Program, which is entitled "Horizon 2020" (EC 2013).

The development of the bioeconomy concept by the institutions of the EU was mirrored by efforts to establish this concept in the EU member states. Germany, for example, established a Bioeconomy Council at the federal level in 2010 under the leadership of the Federal Ministry of Education and Science (BMBF). In 2010, a "National Research Strategy BioEconomy 2030" was published (BMBF 2010), and the federal government pledged to spend 2.4 billion euros for bioeconomy research until 2016 (BMBF 2014, p. 9). In 2013, Germany published a "National Policy Strategy on Bioeconomy". The policy had the subtitle "Renewable resources and biotechnological processes as basis for food, industry and energy", which reflects both the biotechnology innovation perspective and the resource substitution perspective mentioned above (BMEL 2013).

Other European countries also developed policies and strategies related to the bioeconomy. However, there was considerable variation regarding the extent to which these policies and strategies were specifically focused on the bioeconomy or rather on related aspects, such as biotechnology or renewable energy. For example, by 2015 neither France nor Great Britain nor Italy had a strategy that specifically focused on the bioeconomy (BÖR 2015a). Finland, in contrast, had already published a bioeconomy strategy in 2014. Austria and Norway, to mention two other examples, were in the process of preparing a dedicated bioeconomy strategy in 2015 (BÖR 2015b). 


\subsubsection{The Rise of the Bioeconomy as a Global Concept}

The EU is not the only region of the world where the concept of the bioeconomy has been promoted since the early 2000s. As already mentioned in Sect. 3.1.1, the term bioeconomy was probably first used at a meeting of the American Association for the Advancement of Science in 1997. In 2012, the Obama administration released an official strategy on the bioeconomy entitled the "National Bioeconomy Blueprint" (White House 2012). This strategy defines the bioeconomy as follows:

\footnotetext{
A bioeconomy is one based on the use of research and innovation in the biological sciences to create economic activity and public benefit. The U.S. bioeconomy is all around us: new drugs and diagnostics for improved human health, higheryielding food crops, emerging biofuels to reduce dependency on oil, and biobased chemical intermediates, to name just a few. (White House 2012, p. 7)
}

This definition also reflects the two perspectives of the bioeconomy discussed above, the biotechnology innovation perspective and the resource substitution perspective. Other countries, including both industrialized and developing ones, also published bioeconomyrelated policies and strategies in the first two decades of the twenty-first century. For example, Malaysia published a "Bioeconomy Transformation Program" in 2012, and South Africa released a bioeconomy strategy in 2013 (BÖR 2015b). While the number of countries that have dedicated bioeconomy policies is still limited, there are a large number of countries that have strategies related to biotechnology and/or to renewable resources (BÖR 2015b). Figure 3.1 gives a global overview of the state of bioeconomy strategy development achieved in 2017.

In December 2015, the first Global Bioeconomy Summit was held in Berlin. The event was organized by the German Bioeconomy

\section{Bioeconomy Policies around the World}

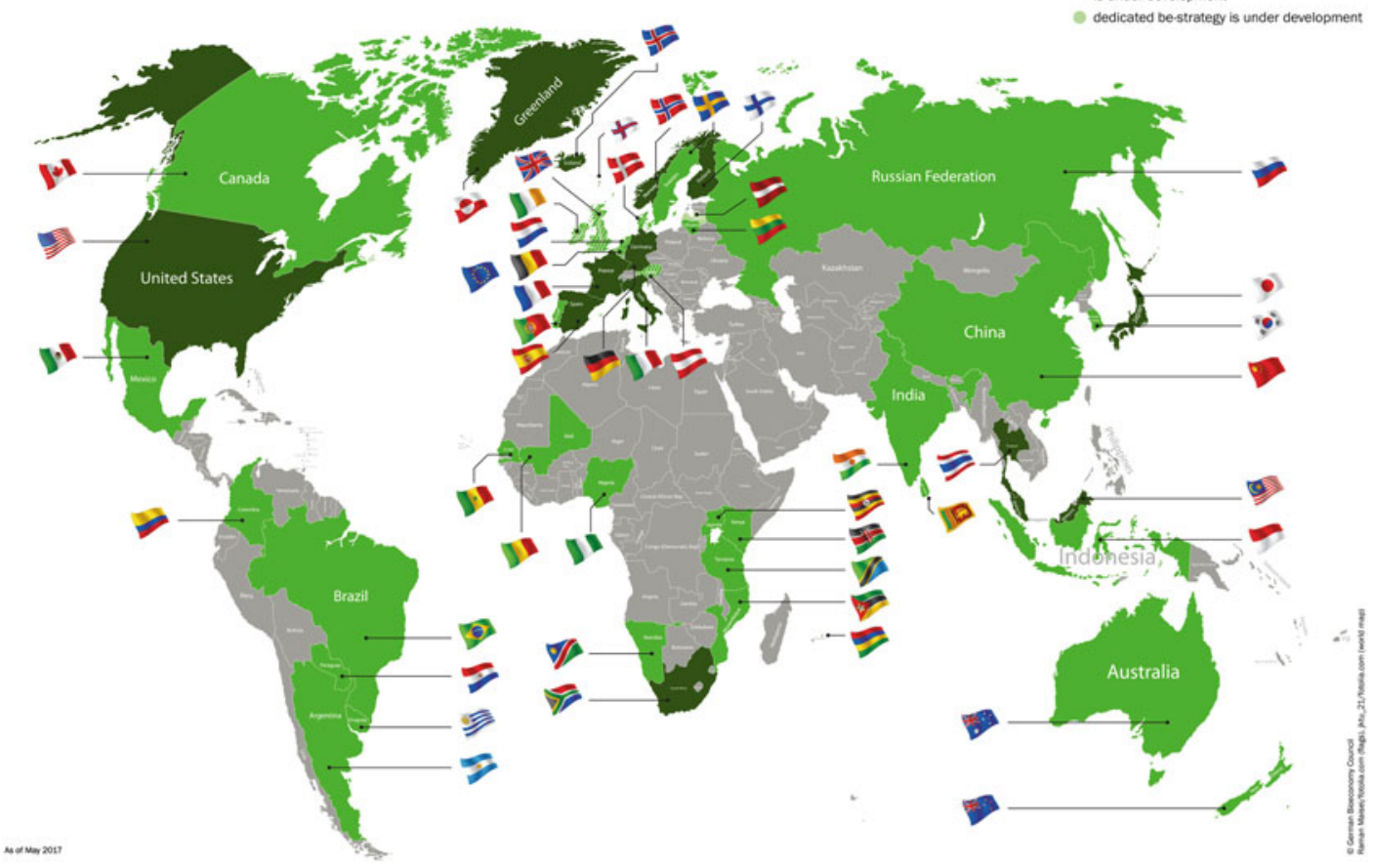

Fig. 3.1 Bioeconomy policies and strategies established by 2017 (BÖR 2017) 


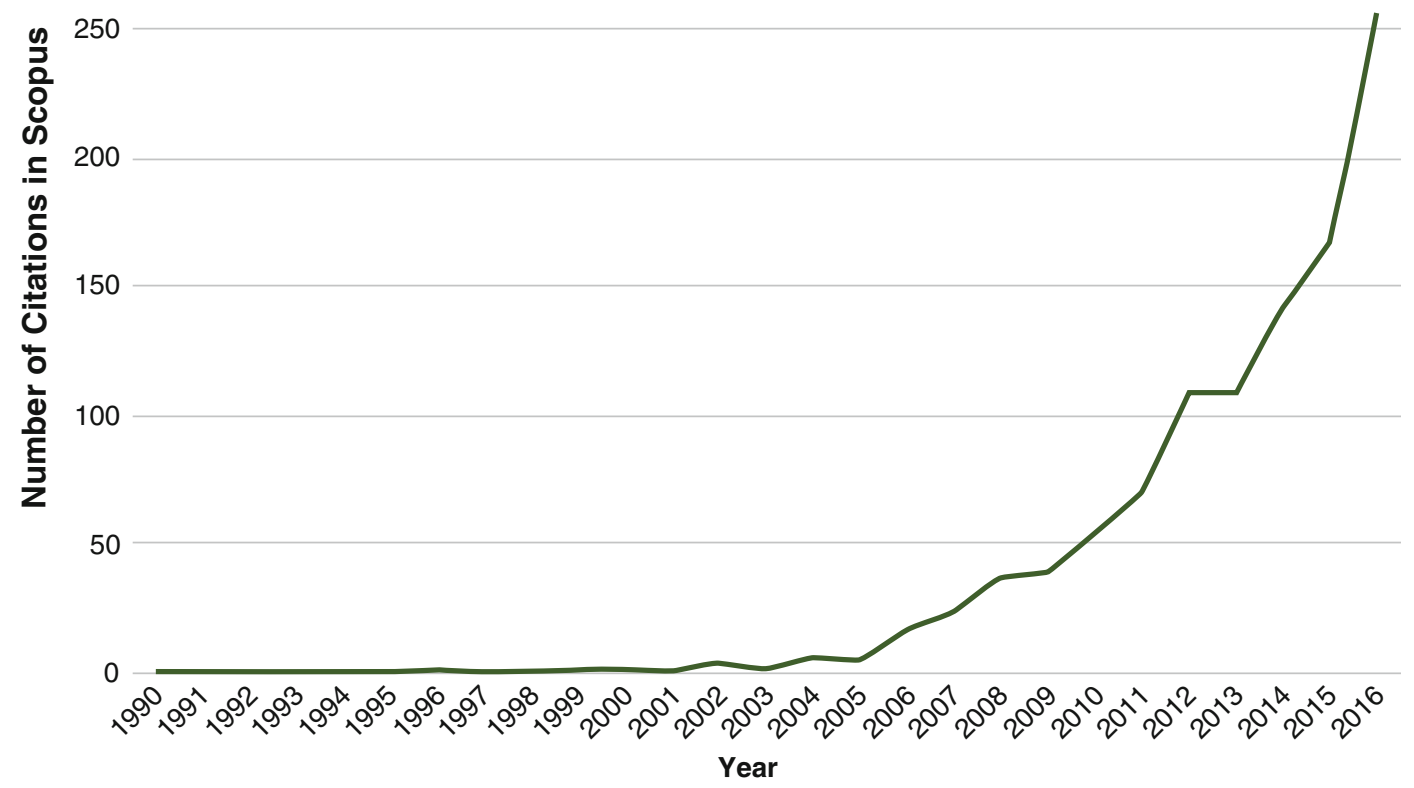

Fig. 3.2 Number of publications listed in Scopus that refer to the bioeconomy. Note: The diagram captures the number of entries that have one of the following expressions in titles, abstracts or keywords: "bio-based

Council in collaboration with an international advisory committee. It brought together more than 700 bioeconomy experts from more than 80 countries (BÖR 2015c, p. 4).

The rise of the bioeconomy as a global concept is not only reflected in the increasing number of countries that have bioeconomy-related strategies and policies but also in the scientific literature. As shown in Fig. 3.2, the number of publications listed in Scopus that refer to the bioeconomy has increased rapidly from 2005 onwards.

\subsubsection{Changing Perspectives on the Bioeconomy}

As shown above, the development of the concept of the bioeconomy was characterized by two perspectives: (1) the resource substitution perspective and (2) the biotechnology innovation economy", "biobased economy", "bioeconomy" or "bioeconomy". Source: Compiled by the authors based on Scopus

perspective. Table 3.1 indicates how the emphasis on these two perspectives changed over time. Even though biotechnology innovation was recognized from the very beginning as an opportunity for the bioeconomy, the resource substitution perspective was more prominent in the first decade of the twenty-first century.

One driving force behind the resource substitution perspective was the concept of "peak oil", which implies that oil extraction rates had reached its peak and that extraction rates would fall after the peak, while oil prices would continuously increase (Bardi 2009). A rising price of oil increases the comparative advantage of using biomass for energy and material use. This line of reasoning promoted the resource substitution perspective of the bioeconomy.

Figure 3.3 illustrates the resource substitution perspective of the bioeconomy. This diagram was developed by the German Bioeconomy Council in 2010 (BÖR 2010). Essential 
Table 3.1 Changing perspectives of the bioeconomy

\begin{tabular}{l|l|l|} 
Perspectives & $\begin{array}{l}\text { Resource substitution perspective (first } \\
\text { decade of the twenty-first century) }\end{array}$ & $\begin{array}{l}\text { Biotechnology innovation perspective (second } \\
\text { decade of the twenty-first century) }\end{array}$ \\
$\begin{array}{l}\text { Relation to } \\
\text { fossil resources }\end{array}$ & "Peak oil", scarcity of fossil energy resources & $\begin{array}{l}\text { New exploration technologies for oil; low, } \\
\text { volatile prices }\end{array}$ \\
$\begin{array}{l}\text { Major driving } \\
\text { forces }\end{array}$ & $\begin{array}{l}\text { Expectation that prices will continue to } \\
\text { increase }\end{array}$ & $\begin{array}{l}\text { Paris climate agreement Advances in the } \\
\text { biological sciences }\end{array}$ \\
$\begin{array}{l}\text { Overall } \\
\text { rationale }\end{array}$ & Resource substitution & Innovation for sustainable development
\end{tabular}

Source: Prepared by the author based on BÖR (2014)

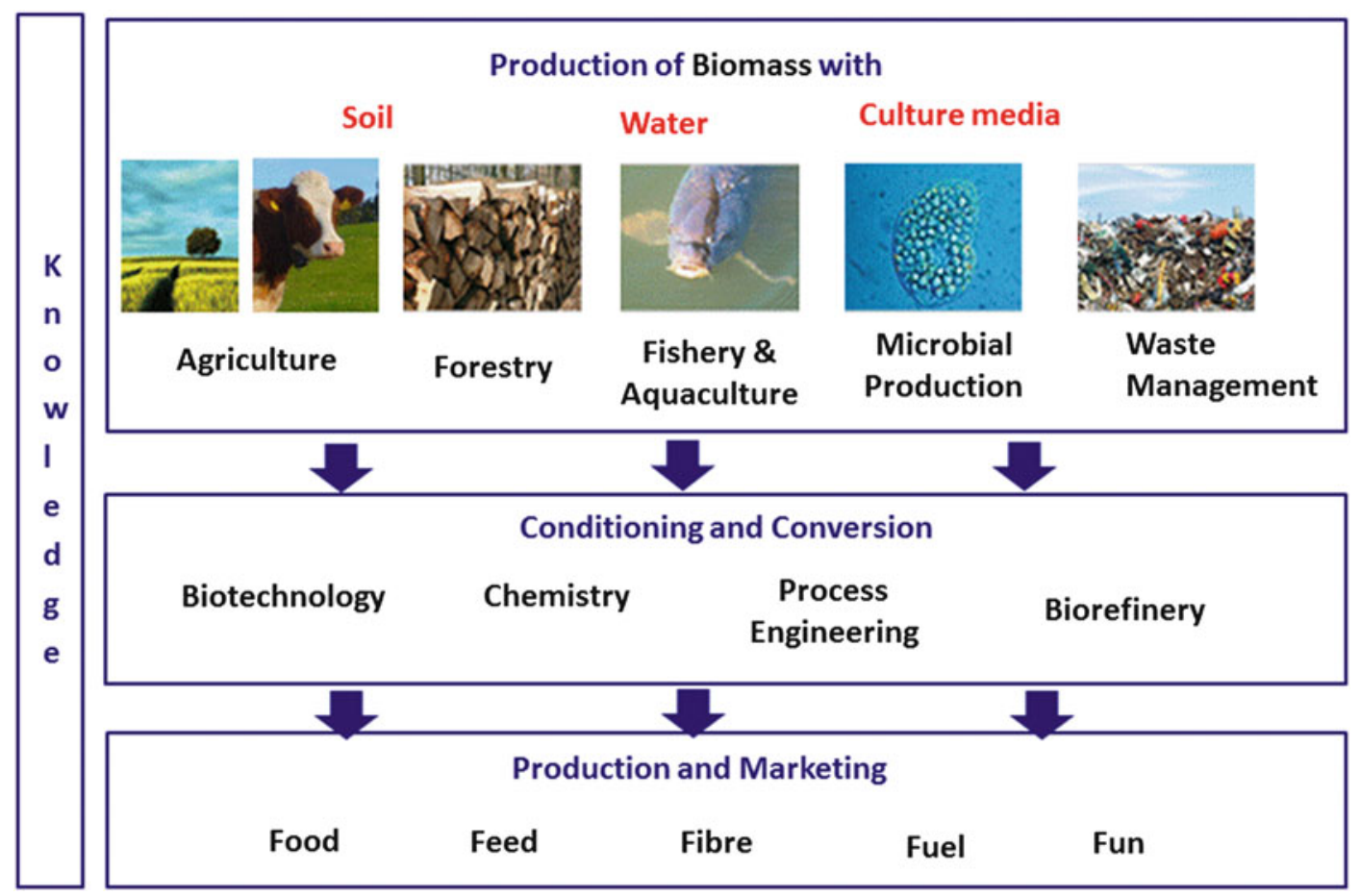

Fig. 3.3 The resource substitution perspective of the bio-economy. Source: BÖR (2010, p. 15)

components of the bioeconomy are, as seen in Fig. 3.3, the production of biomass in various forms, its conditioning and conversion using different procedures and the production and marketing of food, feed, fibre fuel and "fun". The term "fun" refers to products such as flowers.

The oil price crisis of 2007/2008 reaffirmed the "peak oil" perception. The increasing use of food crops for biofuel contributed to the spike in food prices that was observed following the oil price crisis. This development was primarily promoted by high oil prices (Headey and Fan 2008). Biofuel policies, such as biofuel subsidies and mandates to add biofuel to commercial petrol, became subject to increasing criticism, as research established the impact that they can have on food prices (de Gorter et al. 2013).

These developments had two important implications for the bioeconomy: First, the potential tension between ensuring food availability and using biomass for energy purposes became an important topic in the public policy debate surrounding the bioeconomy, as further discussed below. Second, increasing attention was paid to the need to increase the productivity of biomass production and to develop options for 
producing and using biomass that are not in conflict with food availability. Such options include second-generation technologies and the use of by-products and waste products for bioenergy production.

Both energy and food prices fell considerably after 2010, and they also became more volatile as compared to the 1990s (Kalkuhl et al. 2016). The development of the oil price remains difficult to project (Baumeister and Kilian 2016), but in view of the prevailing low oil prices, scarcity of oil was no longer a prominent argument for the resource substitution perspective (Table 3.1). Climate protection became the major argument for substituting fossil-based resources. While this argument was not new (e.g. WBGU 2011), the Paris Agreement under the United Nations Framework Convention on Climate Change became a major rationale for resource substitution (see Table 3.1).

While resource substitution, thus, remains important, the emphasis has shifted to the biotechnology innovation perspective of the bioeconomy. Accordingly, the opportunity to make economic use of innovations in biotechnology and, more generally, in the life sciences has become a major rationale for the bioeconomy in recent years. An example for this shift in perspective is a Strategy Paper published by the German Federal Bioeconomy Council in May 2014, which includes the following section:

\footnotetext{
Originally, the concept of a biobased economy was promoted in the light of expected rapidly depleting petrol, gas and coal reserves. However, the move into bioeconomy is no longer driven predominantly by expectations of rising prices of fossil fuels. In view of the exploitation of new fossil reserves and due to energy efficiency improvements, this argument has become less pressing but it nevertheless remains strategically essential. Without major adjustments, the continued emission of greenhouse gases and the related changes in climate conditions will irreversibly damage the global ecosystem and will involve incalculable economic risks. (BÖR 2014, p. 1)
}

The role of the bioeconomy as an important element in moving towards a more sustainable economic system is an issue further discussed in more detail in Sect. 3.1.6.

\subsubsection{Arising Criticism of the Concept}

The global rise of the concept of the bioeconomy has not been without its critics. One can distinguish two major types of criticism, which one can label the "fundamental critique" and the "greenwashing critique". An example of the fundamental critique is the writings by Birch and co-authors (Birch 2006; Birch et al. 2010). They criticize the bioeconomy as the "neoliberalization of nature". The authors analyse the emerging discourse of the knowledge-based bioeconomy in the EU and criticize that the development of the concept has been dominated by what they refer to as a "neoliberal ideology". Accordingly, the criticism of the bioeconomy concept is linked to a more general critique of "a neoliberal regime in which market values are installed as the over-riding ethic in society and the market rule is imposed on all aspects of life" (Birch 2006, p. 4). Related to this type of criticism is the claim that the concept has been promoted to pursue the interest of big companies, which are interested in commercializing innovations in the life sciences and in applying technologies that are contested in society, such as genetic engineering and synthetic biology. An example of this criticism is a paper by Gottwald and Budde that was published in 2015 on the occasion of the Global Bioeconomy Summit of 2015. These authors also argue that the bioeconomy would promote "land grabbing" and threaten world food security (Gottwald and Budde 2015).

The second type of criticism is not fundamentally opposed to the concept of the bioeconomy but rather warns against the use of this concept for "greenwashing". An example of this type of criticism is a report by the World Wide Fund for Nature published in 2009 (WWF 2009), which is entitled "Industrial biotechnology-More than green fuel in a dirty economy?" This report acknowledges the potential of the bioeconomy to make modern economic systems more environmentally sustainable, but points out that the approaches that have been promoted under the label bioeconomy do not necessarily realize 
this potential. The thrust of this criticism is to ensure that the label "bio" is not misused to portray an essentially non-sustainable economic system as environmentally friendly, but to ensure that innovations in the life sciences are indeed used to ensure a transition towards a sustainable economic system.

The rising criticism against the bioeconomy may have contributed to two trends in the development of the bioeconomy concept, which have become prominent in recent years. One is to embed the concept of the bioeconomy more explicitly into the broader concepts of sustainable development and the green economy. The second trend is a shift in focus from the supply side of the bioeconomy to the demand side, i.e. a shift from technological innovations and companies that commercialize them to the consumers and to society at large. Both trends are described below in more detail.

\subsection{6 "Greening" the Bioeconomy}

The early definitions of the bioeconomy quoted above did not include explicit references to environmental goals, even though environmental sustainability was implicitly assumed both in the biotechnological innovation perspective and in the resource substitution perspective. As the bioeconomy concept was further developed the second decade of the twenty-first century, it was increasingly recognized that environmental goals need to be explicitly included into the concept as the use of biotechnological innovations and the use of bio-based resources are not "automatically" more environmentally friendly than alternative options. The increasing criticism of the use of bioenergy, which was associated with the food price crisis of 2008/2009 (see above), is a particularly pronounced example of this shift in emphasis.

\subsubsection{Bioeconomy and Sustainability}

The increasing concern about ensuring sustainability is reflected in an adjustment of the definition of the bioeconomy. The Communiqué of the Global Bioeconomy Summit of 2015, which was entitled "Making Bioeconomy Work for Sustainable Development", includes the following statement:

\begin{abstract}
Bioeconomy is defined in different ways around the world. We have not aimed for a unified definition but note that an understanding of 'bioeconomy as the knowledge-based production and utilization of biological resources, innovative biological processes and principles to sustainably provide goods and services across all economic sectors' is shared by many. (Bioeconomy Summit 2015, p. 4, emphasis added)
\end{abstract}

The reference to sustainability can be placed within the context of the wider societal goal of "sustainable development". This concept had entered the international policy agenda already in the 1980s. The UN Commission on Environment and Development defined "sustainable development" in its report "Our Common Future" as follows:

\section{development that meets the needs of the present without compromising the ability of future generations to meet their own needs. (WCED 1987, p. 41)}

The Commission on Environment and Development is also known as the Brundtland Commission, named after its chair, Gro Harlem Brundtland, who was then prime minister of Norway and first political leader who came to this position after having been a minister of environment before. As Brundtland points out, the commission aimed at bringing two major concerns together, which had been emerged in the international agenda in previous decades but were hitherto treated rather independently: the concern about environmental problems in industrialized countries on the one hand and the concern about poverty and population pressure in developing countries on the other hand (WCED 1987). The definition of sustainable development reflects the goal to address these two concerns jointly.

The concept of sustainable development was reaffirmed at the "International Conference on Environment and Development" in Rio de Janeiro in 1992, also referred to as the Earth 
Summit. At this conference, the representatives of more than 170 nations passed a major global action program called "Agenda 21", which had four program areas: social and economic dimensions; conservation and management of resources; strengthening major groups, including civil society organizations; and means of implementation (UN 1992). The Agenda 21 promoted the notion that "sustainable development" has three dimensions: an economic, a social and an environmental dimension. Accordingly, the principle that the bioeconomy has to be sustainable covers not only the environmental dimension but also the economic and social dimension. The concept of sustainability and its relevance is further discussed in Sect. 8.2.

\subsubsection{The Bioeconomy as a Component of the Green Economy}

At the Rio+20 Conference in Rio de Janeiro in 2002, the participants adopted a resolution entitled "The future we want" (UN 2012). This resolution reaffirms the principle sustainable development, and it highlights the concept of the "green economy" as "one of the important tools available for achieving sustainable development" (UN 2012, p. 10). The United Nations Environment Program (UNEP) defined a green economy:

as one that results in improved human well-being and social equity, while significantly reducing environmental risks and ecological scarcities [...] In its simplest expression, a green economy can be thought of as one which is low carbon, resource efficient and socially inclusive. (UNEP 2011, p. 16)

In the academic literature, the concept of the green economy has a long history (see review by Loiseau et al. 2016). The question arises as to how the concept of bioeconomy is linked to the concept of the green economy. Ultimately, this is a matter of definition. One option is to consider the bioeconomy as an integral component of the green economy. According to this view, one may consider renewable energy sources that do not rely on biological resources, such as wind and solar energy, as part of the green economy but

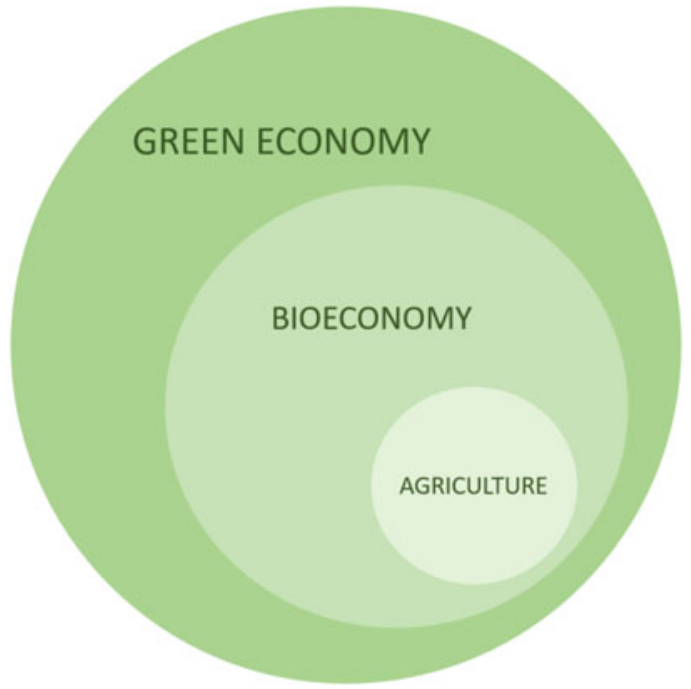

Fig. 3.4 The bioeconomy as a component of the green economy. Source: Authors

not as part of the bioeconomy. Figure 3.4 illustrates this conceptualization.

In the UN resolution "The world we want" mentioned above, the international community also agreed on a process to establish sustainable development goals as a follow-up to the Millennium Development Goals that were agreed upon in 2000 and covered the time period until 2015 (UN 2012, p. 46ff). A set of 17 "Sustainable Development Goals" (SDGs) were adopted by the UN in 2015. Section 8.2 further discusses the role of the SDGs for the bioeconomy.

\subsubsection{Bioeconomy and the Principles of the Circular Economy}

Next to the concept of the green economy, another concept has gained prominence in recent years, which is related to the bioeconomy: the concept of a "circular economy". The Communiqué of the Global Bioeconomy Summit mentioned above emphasizes the need to align the principles of a sustainable bioeconomy with the principles of a circular economy, which "would involve systemic approaches across sectors (i.e. nexus thinking), particularly innovation policy measures that aim at optimizing Bioeconomy value networks and 
minimizing waste and losses" (Bioeconomy Summit 2015, p. 5).

This concept of the circular economy was popularized in a classical textbook on environmental economics by David Pearce and Kerry Turner in 1989 (Pearce and Turner 1989). These authors trace it back to a landmark essay by Kenneth Boulding published in 1966, in which Boulding emphasized the need to manage the economy not as an open system but as a "spaceship", where "man must find his place in a cyclical ecological system which is capable of continuous reproduction of material form" (Boulding 1966, p. 11). Boulding's concepts are further discussed in Sect. 10.2. As a recent review shows, the concept of the circular economy has mostly been associated with the adoption of closing-the-loop production patterns within an economic system, and with aims to increase the efficiency of resource use, placing a specific focus on urban and industrial waste (Ghisellini et al. 2016, p. 11). As such, the concept of the circular economy is narrower in scope than the concepts of the green economy and the bioeconomy. The demand to link the bioeconomy with the principles of the circular economy can, however, play an important role in ensuring that the bioeconomy is, indeed, sustainable. Moreover, the focus on renewable resources and on biotechnological innovations, which are central elements of the bioeconomy, can play an important role in implementing the principles of the circular economy.

The goal to link the bioeconomy with the principles of a circular economy has also led to the development of the concept of a "biomassbased value web" (Virchow et al. 2016). This concept takes into account that the cascading use of biomass and the use of by-products from the processing of biomass lead to an interlinkage of different value chains. These can be analysed as a "value web". Scheiterle et al. (2017) present a case study of Brazil's sugarcane sector. Figure 3.5 illustrates the concept of a value web based on the sugarcane biomass. As can be seen from the diagram, the by-products from the processing of sugarcane, such as filter cake, vinasse and bagasse, are used for the generation of biogas or bioelectricity instead of being disposed as waste. These by-products can also be used for new types of bioeconomy products, such as flavours or pharmaceuticals, thus opening new branches in the biomassbased value web.

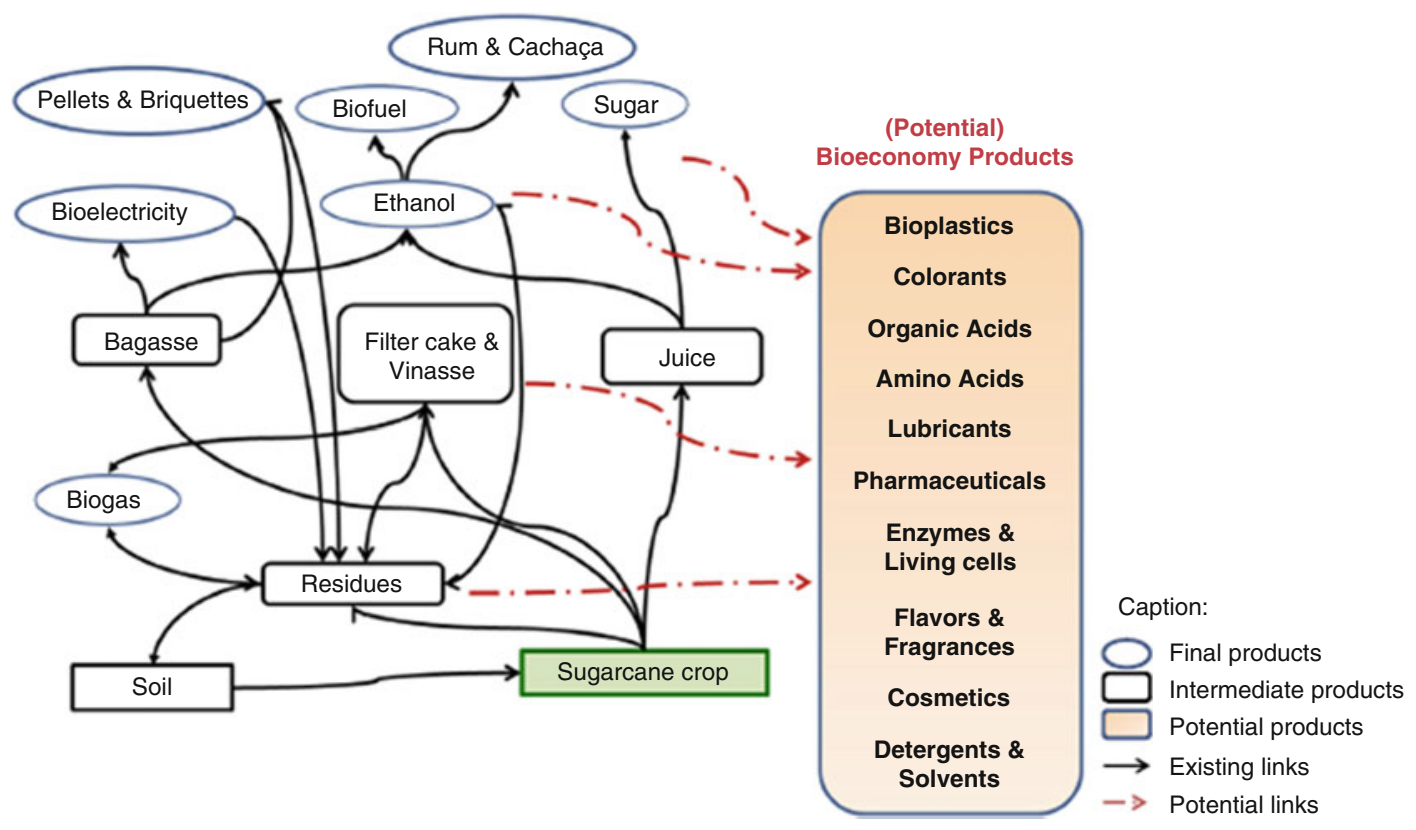

Fig. 3.5 Biomass flows in a value web based on biomass from sugarcane. Source: Scheiterle et al. (2017, p. 6) 


\subsubsection{Bioeconomy as an Element of a "Great Societal Transformation"}

As can be seen from the above definitions, the development of the bioeconomy concept was initially characterized by a focus on the "supply side" of the bioeconomy, that is, by a focus on the supply of goods and services that are based on biological resources and biotechnological processes. In recent years, more emphasis has been placed on the demand side of the bioeconomy and, more generally, on the role of the bioeconomy in society.

Figure 3.6 represents a more holistic view of the bioeconomy, which takes people-as consumers and citizens-explicitly into account. This diagram was developed by a team from the University of Hohenheim as basis for the Master's program "Bioeconomy", which started in 2014.
As shown in the diagram, preferences and values of people, which translate into needs and demands for (new) bio-based products, are as essential for the bioeconomy as is the production of those products. This holistic view of the bioeconomy requires a transdisciplinary systems analysis. The issue of transdisciplinarity is dealt with in Chap. 4.

Taking the societal embeddedness of the bioeconomy a step further, one can also consider the bioeconomy as an element in a process of societal transformation, which is ultimately required to transform the current economic system into one that is economically, environmentally and socially sustainable. The recognition of the challenges involved in this transformation has led to the hypothesis that it will not be sufficient to create economic incentives and implement conducive environmental policies. What is ultimately required is "a great societal transfor-
Fig. 3.6 Holistic concept of the bioeconomy. Source: University of Hohenheim (2013)

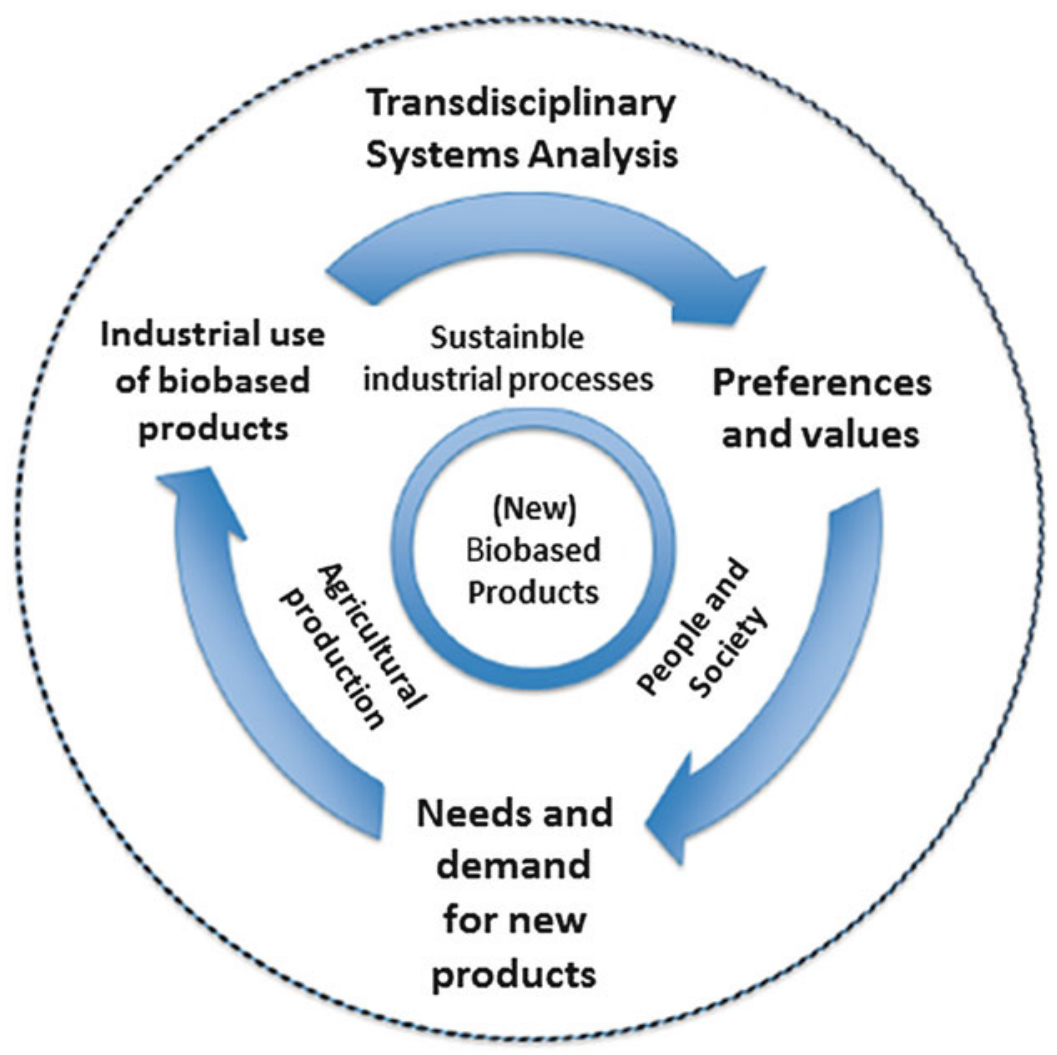


mation", which "encompasses profound changes to infrastructures, production processes, regulation systems and lifestyles, and extends to a new kind of interaction between politics, society, science and the economy" (WBGU 2011, p. 1).
In line with this thinking, Fig. 3.7 places the bioeconomy in a larger historical context. In this perspective, the bioeconomy is conceptualized as an essential element in a new era that will ultimately replace the industrial society. As shown
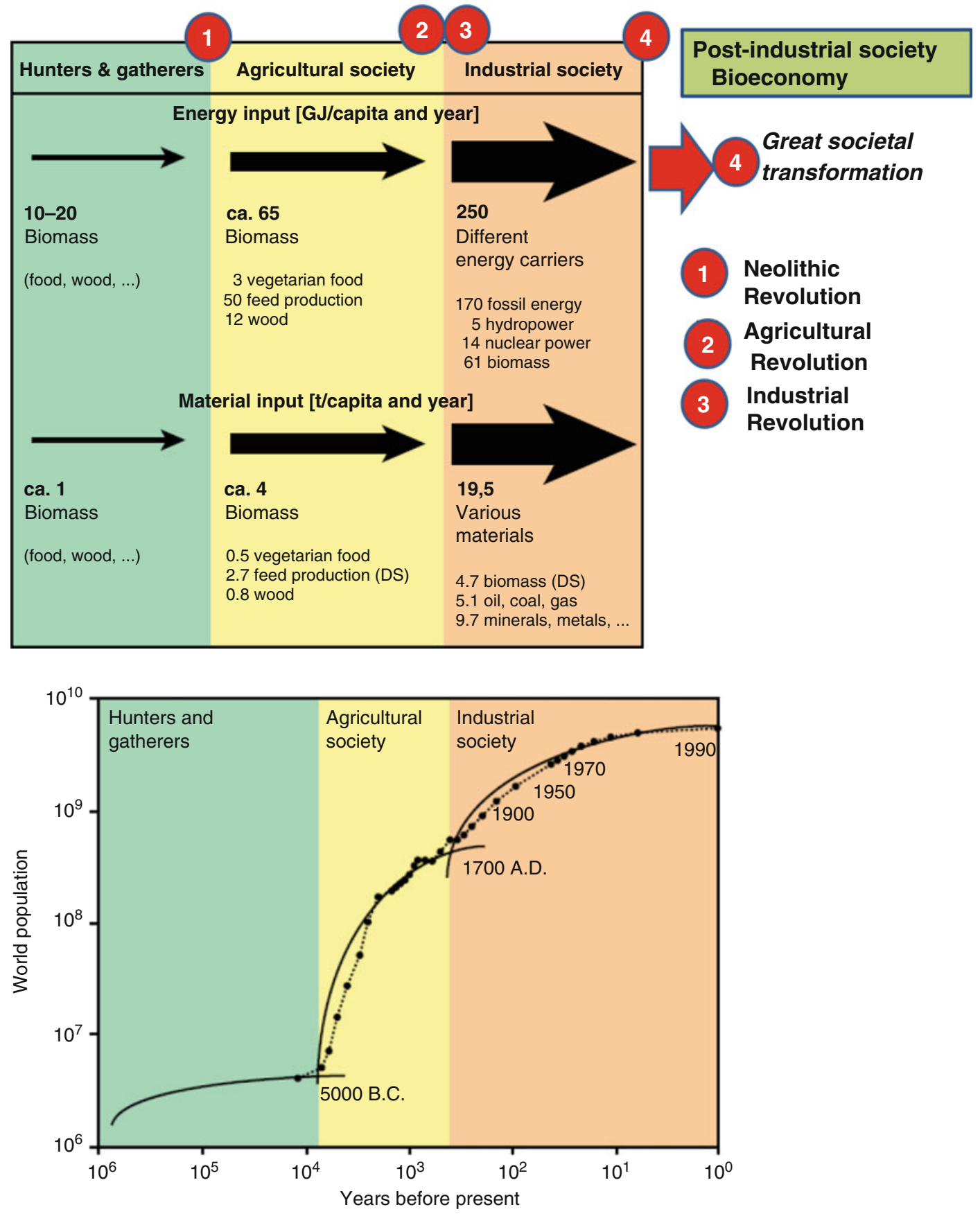

Fig. 3.7 The bioeconomy as an element in societal transformation. Source: Adjusted from WBGU (2011, p. 86) 
in Fig. 3.7, the industrial society followed the agricultural society, which in turn had followed the society of hunters and gatherers. The industrial society was made possible by the industrial revolution and agricultural revolution that preceded it. The agricultural society, in turn, was made possible by the Neolithic Revolution. As shown in Fig. 3.7, the agricultural society and the industrial society were associated with a substantial increase in energy and material use. The lower part of Fig. 3.7 indicates that the transitions to the agricultural and to the industrial society were associated with a steep increase in world population, which has slowed down only in the later phases of the industrial society. Since the transitions to the agricultural and the industrial society were caused by so-called revolutions, it appears justified to assume that the shift to the bioeconomy requires a similar large-scale change. This line of thinking is reflected in the idea of a "great societal transformation" mentioned above (WBGU 2011).

\subsection{Bioeconomy Strategies}

As pointed out in Sect. 3.1.3, an increasing number of countries have adopted bioeconomy strategies or bioeconomy policies. Since the two terms are often used interchangeably, the term "bioeconomy strategies" is used in the following to refer policy documents or strategy documents that have officially been released by national governments or parliaments. The rationale for government intervention in support of the bioeconomy is further discussed in Sect. 10.2. To better understand the bioeconomy strategies that governments have developed, it is useful to take the comparative advantage into account that a country has for developing different components of the bioeconomy. The "diamond model" developed by Porter (1990) provides a conceptual framework, which can be used for determining the competitive advantage of a country's bioeconomy (Birner et al. 2014). Figure 3.8 displays an adapted version of Porter's diamond model.

\subsubsection{Basic Elements of a Bioeconomy Strategy}

The four basic elements of the "diamond" model, which determine the competitive advantage of a country for developing its bioeconomy, are (1) factor conditions; (2) demand conditions; (3) firm structure, strategy and rivalry; and (4) related and supporting industries. Bioeconomy strategies typically aim to promote the bioeconomy by targeting several or all of these
Fig. 3.8 The diamond model of comparative advantage. Source:

Adapted from Porter (1990, p. 127), published in Birner et al. (2014, p. 5)
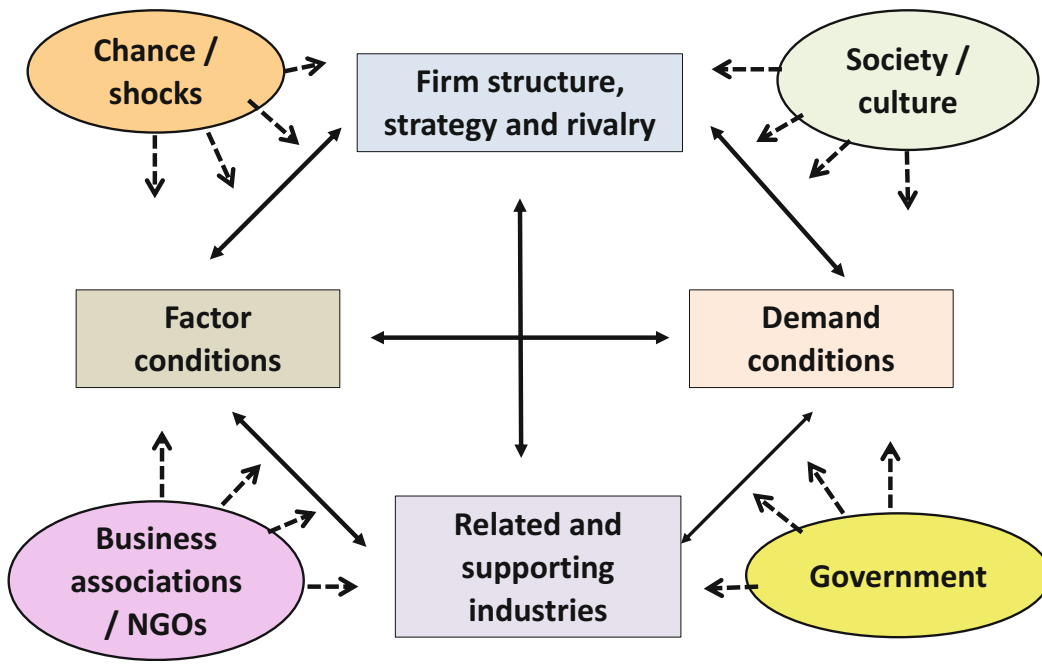

Related and supporting industries

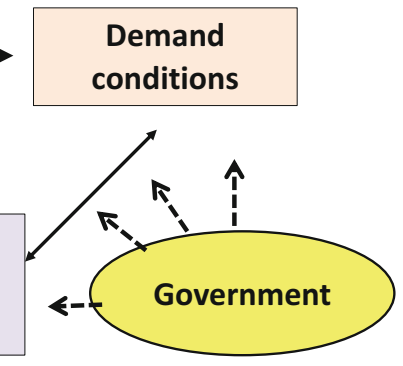


four groups of factors. The Global Competitiveness Report of the World Economic Forum (2016) provides a wide range of indicators related to these groups of factors for 138 countries. Though the indicators are not specific for the bioeconomy, they are still a useful source of information for countries to assess the general conditions for the development of their bioeconomy.

\subsubsection{Upgrading Factor Conditions for the Bioeconomy}

Based on Porter (1990), one can distinguish five types of factor conditions, which are relevant for the development of the bioeconomy:

1. Natural conditions: A country's endowment with land and its agroclimatic conditions have a large influence on a country's competitive advantage for the production of biomass. Countries with large land endowments, favourable agroclimatic conditions and low population density typically have a comparative advantage for emphasizing the resource substitution perspective of the bioeconomy as they can have the potential to produce biomass for bioenergy and bio-based materials (e.g. bioplastic) on a large scale and at comparatively low cost. Brazil, which has a competitive advantage for producing sugarcane, is an example for this type of countries. Countries that have access to marine resources may emphasize these resources in their bioeconomy-related strategies. Norway is an example (BÖR 2015b, p. 108). Countries with less favourable natural resource conditions and/or limited land resources will have to focus more on biotechnology innovation than on resource substitution to develop their bioeconomy.

2. Labour resources: While the basic natural conditions cannot be influenced by government interventions, governments can have a large influence on the qualification of their labour force for the bioeconomy, especially by investing in education and professional training. The development of the bioeconomy requires specific skill sets, and education programs need to be adjusted and developed to enable the labour force to gain those skills. As an example, the University of Hohenheim in Stuttgart, Germany, introduced as an interdisciplinary Master's program called "Bioeconomy" in 2014. In Porter's framework, such investments in education are referred to as "factor upgrading"-which is an important strategy that countries can use to improve their competitive advantage for the development of their bioeconomy.

3. Knowledge resources: One of the most important instruments that governments can use to develop their bioeconomy is investment in public research on bioeconomy to foster innovations. The concept of the "knowledgebased bioeconomy" discussed above emphasizes this aspect. Accordingly, investments in research and innovation are an important element of most bioeconomyrelated strategies (BÖR 2015a, b). Since research by the private sector also plays a key role for developing the bioeconomy, creating a conducive environment for research in the private sector is important as well.

4. Capital resources: The development of the bioeconomy relies on investments along the entire value chains for bioeconomy products, including research, product development and marketing. The availability of capital, especially venture capital for risky investments, is therefore an essential condition for the development of the bioeconomy.

5. Infrastructure: Governments can also support the development of the bioeconomy by providing a supportive infrastructure, especially in terms of transport as well as information and communication technologies (ICTs). An important task is the identification of infrastructure needs that are particularly relevant for the bioeconomy strategy selected. 


\subsubsection{Strengthening the Demand for Bioeconomy Products}

An important incentive for the development of the bioeconomy is a strong demand of consumers for bio-based products. Governments can foster this demand by promoting labels for bio-based products that facilitate consumer choice and by conducting information campaigns and fostering social dialogue. Governments can also implement rules for public procurement that strengthen the pubic demand for bio-based products. The analysis of national economy strategies around the world conducted by the German Bioeconomy Council (BÖR 2015a) showed that such demandside instruments play an important role in many bioeconomy strategies. An interesting example of this approach is the BioPreferred ${ }^{\mathbb{B}}$ Program of the United States Department of Agriculture (USDA). This program combines a voluntary labelling initiative for bio-based products with mandatory purchasing requirements for federal agencies and their contractors, which encompasses 97 product categories (https:// www.biopreferred.gov/BioPreferred/).

\subsubsection{Fostering Competition Among Bioeconomy Firms}

It is an important insight from Porter's (1990) analysis that a strong competition of companies in their home countries fosters their international competitive advantage because such competition forces them to be innovative and strategic. At times, governments chose to select and subsidize "champions" and protect them from competition. However, as Porter's comparative historical studies show, this strategy has hardly ever been successful in enabling companies to gain international competitive advantage. This insight can be applied to the bioeconomy, as well. Fostering competition among firms engaged in the bioeconomy and restricting market dominance among them can be seen as an important element of a bioeconomy strategy. The review of bioeconomy strategies by the German
Bioeconomy Council indicates, however, that this aspect has attracted relatively limited attention, so far (BÖR 2015a, b).

\subsubsection{Strengthening Bioeconomy Clusters}

A striking feature of the bioeconomy strategies around the world is the emphasis that they place on the development of clusters (BÖR 2015a, b). The concept of industry clusters or innovation clusters is based on the insight that the development of the bioeconomy requires a strong and regionally integrated network of industries that are related and supporting each other along the value chain, e.g. by providing specialized inputs and services. Clusters also benefit from a close interaction of research organizations, start-up companies that are often spin-offs of research organizations and companies that have the capacity to engage in product development and access large markets. Historical experience indicates that governments have limited capacity to create clusters from scratch. A more promising strategy is to identify emerging clusters and supporting them (Porter 1990). Bioeconomy clusters may also form regional networks. An example is the "3BI intercluster", a partnership of bioeconomy clusters located in France, Germany, the Netherlands and the United Kingdom (http://www.3bi-intercluster.org/home/).

\subsubsection{Using Chances and Shocks as Opportunities for Bioeconomy Development}

The comparative historical studies of Porter (1990) have shown that factors that are beyond the control of economic and political actors can play an important role in determining the competitive advantage of an industry. These factors may be positive ("chances"), such as discoveries that offer unexpected opportunities for the bioeconomy, or negative ("shocks"), such as sudden price changes or natural disasters (see 
Fig. 3.8). These insights from general economic studies can also be applied to the bioeconomy. Ultimately, it depends on the actions of governments and/or private businesses whether opportunities that arise from chances or shocks are effectively used. For example, the oil price crisis of 1973 induced the government of Brazil to establish a National Alcohol Program in 1975, which subsequently played an important role in the development of Brazil's sugar-based bioeconomy (cf. Scheiterle et al. 2017). Likewise, the nuclear disaster of Fukushima in 2011 was a major factor behind the political decision of the German government to get out of nuclear energy and focus on renewable energy, a decision referred to as "Energy Turn" (Energiewende).

\subsubsection{Considering Sociocultural Factors}

As indicated in Fig. 3.8, sociocultural factors play an important role for the development of the bioeconomy, as well. Just as chances and shocks (see above), these factors are also beyond the immediate control of political or economic actors. Yet, they can influence the development of the bioeconomy in various ways. A case in point is genetically modified organisms (GMOs). Proponents of GMOs argue that they can play an important role in the bioeconomy, e.g. by improving the efficiency of producing or converting biomass. However, in most countries of Europe, the use of GMOs in agriculture is not accepted by consumers, and, therefore, GMOs are not used in agriculture. This exclusion of a technology for sociocultural reasons may, however, foster the efforts to develop alternative technologies, such as crop breeding methods based on statistical methods. Countries may then gain a competitive advantage in such alternative technologies.

\subsection{Governance of the Bioeconomy}

The previous sections of this chapter have dealt with the questions of how the bioeconomy can be defined, how the concept has evolved and how the bioeconomy can be promoted. This final section deals with the question of bioeconomy governance. The term governance is used here to refer to the institutions, processes and actors that are relevant for the development of the bioeconomy.

\subsubsection{Overview}

Figure 3.9 displays a conceptual framework that can be used to analyse the bioeconomy governance. The framework distinguishes between three different types of organizations: organizations of the private sector, organizations of the public sector and civil society organizations, which are referred to as the "third sector". Research organizations are mostly public sector organizations. They are depicted separately in view of their important role for the knowledgebased bioeconomy. The media are also depicted separately in view of their role in political processes. Typically, they are organizations of the private sector. Citizens are placed in the centre of the diagram. They are closely interlinked with all sectors, as further discussed below.

The development of the bioeconomy depends on the various interactions among the different actors depicted in Fig. 3.9. The different actors may have converging or conflicting interests, which will result in political and economic processes that may be more or less conducive to the bioeconomy. The governance of the bioeconomy is an interesting new area of research. Existing studies have focused on selected aspects, e.g. the governance of biofuel policies (see, e.g. Bailis and Baka 2011). However, comprehensive studies on the governance of the bioeconomy are still scarce. Therefore, the following sections provide conceptual considerations, which may be explored in more detail by empirical studies in the years to come.

\subsubsection{Private Enterprises and Business Associations}

In a market economy-which is after the fall of the Soviet Union the dominant economic system 


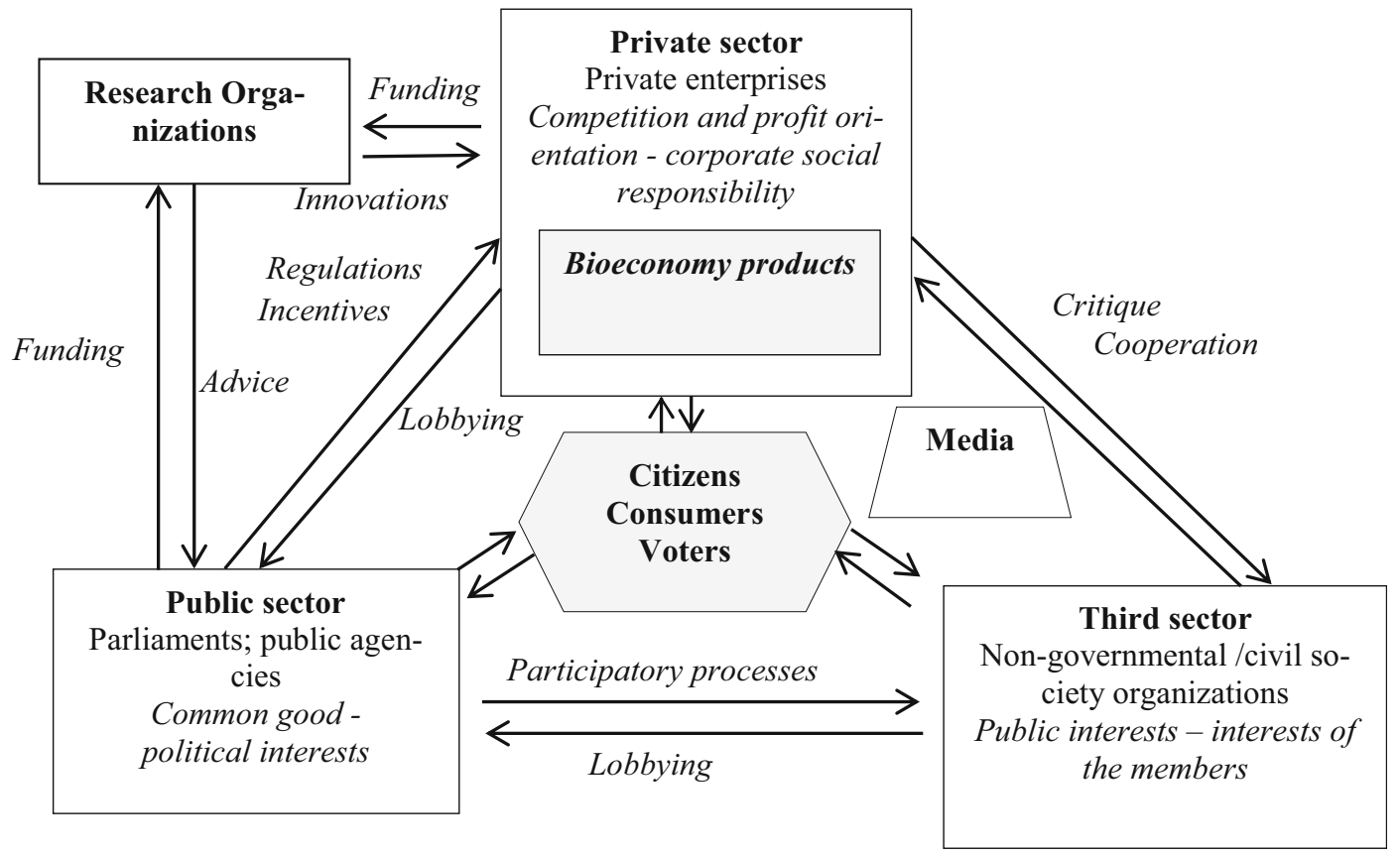

Fig. 3.9 Governance of the bioeconomy. Source: Author

in most countries of the world-private companies are, next to the consumers, the main actors in the bioeconomy. Bioeconomy products and services are, as indicated in Fig. 3.9, mostly produced by private companies. They are subject to competition and they need to make profit to survive, but they can also exercise corporate social responsibility. An interesting potential of the bioeconomy lies in the fact that the bioeconomy creates new opportunities for a wide range of different types of private sector companies-ranging from the small start-up that explores new biotechnology innovations to the well-established large-scale manufacturers of consumer goods that may decide to introduce bio-based materials.

One of the challenges of bio-based companies is the fact that they are distributed across many different industry branches and that they are, therefore, not represented by traditional industry associations. Companies that engage in the production of bio-based products may even face stiff competition, both economically and politically, from companies that rely on fossil-based resources. However, over time, companies that are engaged in the bioeconomy may form new types of business associations and start to play a role in lobbying for the bioeconomy.

As indicated in Fig. 3.9, bioeconomy companies can benefit from government policies, such as support programs. The various strategies that governments can use to support the bioeconomy fall under the linkages between private and public sector depicted in Fig. 3.9. Bioeconomy companies may also benefit from research on bioeconomy that is funded by the public sector, and they may co-fund research together with the government. Bioeconomy companies and their associations may lobby the government with the aim to induce the government to support the development of the bioeconomy. However, companies that rely on fossil resources may lobby the government, as well, which may slow down the development of the bioeconomy.

\subsubsection{Consumers/Citizens/Voters}

In a market economy, consumers are, next to companies, the main economic actors in the bioeconomy. Therefore, policy instruments, 
such as labels for bio-based products, can play an important role in promoting the bioeconomy, as mentioned above. In the political system, consumers also play a central role as citizens and voters. If they are interested in the bioeconomy, they may consider the extent to which political parties foster the development of the bioeconomy and this may influence their voting decision. Citizens may also be critical of the bioeconomy, as discussed in Sect. 3.1.5. Citizens become more effective political actors, however, if they organize themselves in the form of civil society organizations, as discussed in the next section. Figure 3.9 also indicates that they are influenced by the media, which may report positively or negatively about the bioeconomy.

\subsubsection{Public Sector Organizations}

As has been discussed in Sect. 3.2, public sector organizations can play an important role in fostering the development of the bioeconomy. Governments can use various policy instruments to promote the bioeconomy, as discussed above. Governments may use the existing public administration to implement bioeconomy strategies, or they may create special agencies. So far, special agencies have mostly been established for specific components of the bioeconomy, such as renewable resources or biofuels. As further discussed below, the coordination between different ministries and agencies constitutes one of the governance challenges of the bioeconomy.

\subsubsection{Research Organizations}

Research organizations that carry out research related to the bioeconomy are typically public sector organizations, as mentioned above. However, they often enjoy a degree of independence that sets them apart from other government agencies. They play an important role for the bioeconomy, especially by conducting research using public funding. They may, however, also receive funding from the private sector and engage in joint research activities. As discussed in Chap. 4 in more detail, research organizations can involve a wide variety of stakeholders beyond industry partners by applying transdisciplinary research approaches. Members of research organizations may also influence government policies and public opinion by participating in Scientific Advisory Councils related to the bioeconomy.

\subsubsection{Third Sector Organizations}

Civil society organizations, also referred to as non-governmental organizations (NGOs), play an important role in democratic systems. Since they differ from both public and private organizations in terms of organizational structure and the nature of their interests, they are often referred to as "third sector". NGOs typically pursue public interests, such as environmental protection or social justice, which correspond to the interests of their constituents. They are based on principles of collective action and are often organized in networks rather than hierarchical structures. They interact with government, e.g. by lobbying or by participating in other ways in policy processes, e.g. by being members of round tables. Since the bioeconomy is still emerging, NGOs that specifically pursue public interests related to the bioeconomy have hardly emerged yet. However, well-established environmental organizations have started to deal with the bioeconomy. As has been pointed out in Sect. 3.1.5, some of them view the bioeconomy rather critically. This is, however, not necessarily an obstacle. To the contrary, by taking a critical perspective, NGOs can play an important function in creating pressure to ensure that the bioeconomy is indeed environmentally sustainable (see Sect. 3.1.6).

\subsubsection{Governance Challenges}

As can be derived from Fig. 3.9, the bioeconomy is governed by a network of actors from different sectors that have partly aligned and partly conflicting interests. They interact through a variety of processes, which leads to various 
governance challenges. Three types of governance challenges are discussed here in more detail.

Political Economy Challenges Governments can play a far-reaching role by creating conducive frame conditions for the development of the bioeconomy, as has been pointed out above. However, governments are themselves subject to a variety of forces, such as lobbying by industry groups and civil society organizations, which may not necessarily be in favour of the bioeconomy. Bioeconomy policies are, thus, the outcome of conflicting political processes. Examples of such controversial policy fields include biofuel policies (Deppermann et al. 2016) or biotechnology regulations (see, e.g. Richardson 2012).

Participatory and deliberative policy processes have a considerable potential in improving the policy processes related to the bioeconomy. An example is the EU BIOSTEP project, which aims at "Promoting Stakeholder Engagement and Public Awareness for a Participative Governance of the European Bioeconomy" (www.bio-step. eu). The project is supported by the European Union. Mustalahti (2017) presents an interesting recent example from Finland of including citizens in the forest-based bioeconomy with the aim to ensure responsive governance.

Coordination Challenges Another challenge of bioeconomy governance is coordination. Fostering the bioeconomy requires collaboration among different ministries, such as the ministries in charge of the economy, agriculture, the environment as well as research and education. Setting up inter-ministerial working groups may help to address this challenge, as the example of such a group in the German federal government shows. There is, however, also a need to establish coordination mechanisms across the public, the private and the third sectors and across different levels of government, especially in federal systems. At present, such coordination mechanisms are still emerging.
Global Bioeconomy Governance Global governance mechanisms for the bioeconomy will be essential to address global concerns, such as reconciling food security with an increasing production of biomass and agreeing on joint international standards for ensuring sustainability in the bioeconomy. Even though there is increasing global interest, as documented by the Global Bioeconomy Summit of 2015, global governance mechanisms still need to be developed. This may require a better integration of the concept of bioeconomy into the global processes related to sustainable development, which are coordinated by the United Nations (see Sect. 3.1.6).

\section{Review Questions}

- How is the bioeconomy defined and how did this concept evolve over time?

- What characterizes the resource substitution perspective of the bioeconomy on the one hand and the biotechnology innovation perspective on the other hand?

- Which types of criticism have been formulated against the concept of the bioeconomy?

- What are the relations between the concept of the bioeconomy and the concepts of sustainable development, green economy, circular economy and the great societal transformation?

- What are the policy instruments that governments can use to promote the development of the bioeconomy?

- Who are the main actors in the bioeconomy, and through which types of processes do they interact with each other?

- What are some challenges regarding the governance of the bioeconomy?

\section{References}

Bailis R, Baka J (2011) Constructing sustainable biofuels: governance of the emerging biofuel economy. Ann Assoc Am Geogr 101(4):827-838. https://doi.org/10. 1080/00045608.2011.568867 
Bardi U (2009) Peak oil: the four stages of a new idea. Energy 34(3):323-326. https://doi.org/10.1016/j. energy.2008.08.015

Baumeister C, Kilian L (2016) Forty years of oil price fluctuations: why the price of oil may still surprise us. J Econ Perspect 30(1):139-160

Bioeconomy Summit (2015) Communiqué of the global bioeconomy summit 2015: making bioeconomy work for sustainable development, Berlin

Birch K (2006) The neoliberal underpinnings of the bioeconomy: the ideological discourses and practices of economic competitiveness. Genomics Soc Policy 2 (3):1-15. https://doi.org/10.1108/00242530610667558

Birch K, Levidow L, Papaioannou T (2010) Sustainable capital? The neoliberalization of nature and knowledge in the European "knowledge-based bio-economy”. Sustainability 2(9):2898-2918. https://doi.org/10.3390/su2092898

Birner R, Isermeyer F, Lange C et al (2014) Die Wettbewerbsfähigkeit der Bioökonomie in Deutschland nachhaltig stärken. Hintergrundpapier German Bioeconomy Council (Bioökonomierat BÖR), Berlin

BMBF (2010) National research strategy bioeconomy 2030 - our route towards a biobased economy. Federal Ministry of Education and Research (BMBF), Berlin

BMBF (2014) Wegweiser Bioökonomie. Bundesministerium für Bildung und Forschung (BMBF) (Federal Ministry of Education and Research), Berlin

BMEL (2013) National policy strategy on bioeconomy renewable resources and biotechnological processes as a basis for food industry and energy. Federal Ministry of Food and Agriculture in Germany (BMEL), Berlin

Bonaiuti M (2014) Bio-economics. In: D'Alisa G, Dematia F, Kallis G (eds) Degrowth: A vocabulary for a new era. Routledge/Taylor \& Francis Group, Abingdon/Oxon, pp 52-55

BÖR (2010) Bio-economy council report 2010: bio-economy innovation. German Bioeconomy Council (Bioökonomierat - BÖR), Berlin

BÖR (2014) Positions and strategies of the German bioeconomy - decided at the 8 th session of the council 14.5.2014 German Bioeconomy Council (Bioökonomierat - BÖR), Berlin

BÖR (2015a) Bioeconomy policy - synopsis and analysis of strategies in the G7. German Bioeconomy Council (Bioökonomierat - BÖR), Berlin

BÖR (2015b) Bioeconomy policy (Part II) - synopsis of national strategies around the World German Bioeconomy Council (Bioökonomierat - BÖR), Berlin

BÖR (2015c) Global bioeconomy summit conference report - for a global sustainable bioeconomy. German Bioeconomy Council (Bioökonomierat - BÖR), Berlin

BÖR (2017) Bioeconomy policies and strategies established by 2017. Diagram prepared by the German
Bioeconomy Council (Bioökonomierat - BÖR), Berlin

Boulding KE (1966) The economics of the coming spaceship earth - environmental quality in a growing economy. In: Jarrent H (ed) Essays from the sixth resources for the future forum on environmental quality in a growing economy. Johns Hopkins University Press, Baltimore, pp 3-14

de Gorter H, Drabik D, Just DR (2013) How biofuels policies affect the level of grains and oilseed prices: theory models and evidence. Glob Food Sec 2 (2):82-88

Deppermann A, Offermann F, Puttkammer J et al (2016) EU biofuel policies: income effects and lobbying decisions in the German agricultural sector. Renew Energy 87:259-265. https://doi.org/10.1016/j.renene. 2015.10.005

EC (2005) New perspectives on the knowledge-based bio-economy - conference report. European Commission (EC), Brussels

EC (2013) Horizon 2020 - the EU framework programme for research and innovation. European Commission, Brussels

Enriquez J (1998) Genomics and the world's economy. Science 281(5379):925-926. https://doi.org/10.1126/ science.281.5379.92

EU (2000) Lisbon European Council 23 and 24 March 2000 - Presidency Conclusions Council of the European Union Lisbon. http://www.consilium. europa.eu/en/uedocs/cms_data/docs/pressdata/en/ec/ 00100-r1.en0.htm. Accessed 15 July 2017

EU (2007) En route to the knowledge-based bio-economy ("Cologne Paper") German Presidency of the Council of the European Union (EU), Cologne

Geoghegan-Quinn M (2013) Role of research and innovation in agriculture. Speech at the European Parliament on June 4 2013, Brussels

Ghisellini P, Cialani C, Ulgiati S (2016) A review on circular economy: the expected transition to a balanced interplay of environmental and economic systems. J Clean Prod 114:11-32. https://doi.org/10. 1016/j.jclepro.2015.09.007

Glick JL (1982) The industrial impact of the biological revolution. Technol Soc 4(4):283-293. https://doi.org/ 10.1016/0160-791X(82)90005-7

Gottwald FT (2016) Bioeconomy - a challenge to integrity. In: Westra L, Gray J, D'Aloia A (eds) The common good and ecological integrity: human rights and the support of life. Earthscan/Routledge, London/New York, pp 22-35

Gottwald F-T, Budde J (2015) Mit Bioökonomie die Welt ernähren? Institut für Welternährung - World Food Institute e.V., Berlin

Headey D, Fan S (2008) Anatomy of a crisis: the causes and consequences of surging food prices. Agric Econ 39(Suppl 1):375-391. https://doi.org/10.1111/j.15740862.2008.00345.x 
Kalkuhl M, von Braun J, Torero M (2016) Volatile and extreme food prices, food security and policy: an overview. In: Kalkuhl M, von Braun J, Torero M (eds) Food price volatility and its implications for food security and policy. Springer Open, Cham, pp 3-31

Loiseau E, Saikku L, Antikainen R et al (2016) Green economy and related concepts: an overview. J Clean Prod 139:361-371. https://doi.org/10.1016/j.jclepro. 2016.08.024

Mustalahti I (2017) The responsive bioeconomy: the need for inclusion of citizens and environmental capability in the forest based bioeconomy. J Clean Prod. https:// doi.org/10.1016/j.jclepro.2017.06.132

Pearce DW, Turner KR (1989) Economics of natural resources and the environment. Johns Hopkins University Press, Baltimore

Porter M (1990) The competitive advantage of nations. Free Press, New York

Potočnik J (2005) Transforming life sciences knowledge into new sustainable eco-efficient and competitive products. Speech held at the Conference on Knowledge-based Bio-economy Brussels 15 September 2005 at the European Commission Brussels

Richardson B (2012) From a fossil-fuel to a biobased economy: the politics of industrial biotechnology. Environ Plan C: Polit Space 30(2):282-296

Scheiterle L, Ulmer A, Birner R, et al (2017) From commodity-based value chains to biomass-based value webs: the case of sugarcane in Brazil's bioeconomy. J Clean Prod (forthcoming). https://doi. org/10.1016/j.jclepro.2017.05.150

UN (1992) Agenda 21. United Nations Conference on Environment and Development Rio de Janeiro Brazil 3 to 14 June 1992. https://sustainabledevelopment.un. org/outcomedocuments/agenda21. Accessed 15 July 2017

UN (2012) The future we want. Resolution adopted by the General Assembly United Nations Sixth Session 22 September 2012 A/Res/66/288

UNEP (2011) Towards a green economy: pathways to sustainable development and poverty eradication. United Nations Environment Programme (UNEP). https://www.unep.org/greeneconomy. Accessed 15 July 2017

University of Hohenheim (2013) Concept for the Development of an M.Sc. Program "Bioeconomy". Unpublished manuscript. Stuttgart

Virchow D, Beuchelt TD, Kuhn A et al (2016) Biomassbased value webs: a novel perspective for emerging bioeconomies in Sub-Saharan Africa. In: Gatzweiler FW, von Braun J (eds) Technological and institutional innovations for marginalized smallholders in agricultural development. Springer, Berlin, pp 225-238

von Braun J (2014) Bioeconomy and sustainable development - dimensions. Rural 21(2):6-9

WBGU (2011) World in transition: a social contract for sustainability German advisory council on global change (Wissenschaftlicher Beirat für Globale Umweltveränderungen - WBGU), Berlin

WCED (1987) Our common future. World Commission on Environment and Development (WCED)/Oxford University Press, Oxford

White House (2012) National Bioeconomy Blueprint. Washington, DC

World Economic Forum (2016) The global competitiveness report 2016/2017. World Economic Forum, Geneva

WWF (2009) Industrial biotechnology - more than green fuel in a dirty economy? World Wide Fund for Nature (WWF), Copenhagen

Open Access This chapter is licensed under the terms of the Creative Commons Attribution 4.0 International License (http://creativecommons.org/licenses/by/4.0/), which permits use, sharing, adaptation, distribution and reproduction in any medium or format, as long as you give appropriate credit to the original author(s) and the source, provide a link to the Creative Commons license and indicate if changes were made.

The images or other third party material in this chapter are included in the chapter's Creative Commons license, unless indicated otherwise in a credit line to the material. If material is not included in the chapter's Creative Commons license and your intended use is not permitted by statutory regulation or exceeds the permitted use, you will need to obtain permission directly from the copyright holder. 